\title{
THE CONCEPT OF FAITH IN THE LETTER OF JAMES: A DISCOURSE ANALYSIS ON JAMES 1-2
}

\author{
Chandra Gunawan
}

Theologische Universiteit Kampen

\begin{abstract}
James' teaching about faith has been downplayed for so many years. Since the concept of faith in the NT has been read mainly in light of Paul's theology, scholars ignores James' teaching on faith, which has different emphasis from Paul. Biblical scholars and theologians have tried to solve the tension between Paul's teaching about faith and James'. While historical approach applied to deal with this issue has lead NT scholarship to enless debate, this study proposes that the Letter of James was not sent to handle problems that occur because of Paul. This essay uses discourse analysis to understand how the the concept of faith in James 1 and 2 should be grasped. This work finds that James addresses his letter to pastoral believers' community and help them to understand sufferings in their lives. James emphasizes that faith is not only a confession but also a commitment to live in accordance with the true belief.
\end{abstract}

KEYWORDS: James, discourse analysis, faith, sufferings, believers' community.

ABSTRAK: Ajaran Yakobus mengenai iman telah diabaikan selama bertahun-tahun. Karena konsep iman dalam Perjanjian Baru dibaca terutama dalam kaca mata teologi Paulus, banyak ahli yang kemudian mengabaikan ajaran Yakobus mengenai iman, yang memiliki penekanan berbeda dari Paulus. Banyak ahli dalam bidang studi biblika dan dogmatika telah mencoba menyelaraskan ketegangan antara ajaran Paulus dan Yakobus tentang iman. Sementara pendekatan historis yang digunakan untuk 
menyelesaikan isu ini telah membawa studi Perjanjian Baru kepada sebuah debat yang tidak kunjung selesai, tulisan ini hendak menunjukkan bahwa surat Yakobus tidak dikirimkan untuk mengangani masalah-masalah yang muncul karena Paulus. Essay ini menggunakan metode discourse analysis untuk memahami bagaimana konsep iman dalam Yakobus 1 dan 2 seharusnya dipahami. Tulisan ini menemukan bahwa Yakobus mengirimkan suratnya untuk menggembalakan komunitas orang percaya dan untuk membantu mereka memahami penderitaan dalam hidup mereka. Yakobus menekankan bahwa iman bukanlah sekedar pengakuan lidah tetapi sebuah komitmen untuk hidup sesuai dengan kebenaran iman yang seseorang perang dan percayai.

KATA KUNCI: Yakobus, analisa diskursus, iman, penderitaan, komunitas orang percaya.

\section{Introduction}

The concept of faith in the Letter of James (LOJ) has become a controversial issue for so many years. Roman Catholic, Lutheran, Calvinist, Anglicans, and other denominations have not been able to reach agreement concerning the issue. ${ }^{1}$ Although ecumenical movements have softened disagreements between major denominations, notably between the Roman Catholic and Lutheran, ${ }^{2}$ the gulf of understanding between different denominations regarding this issue is still wide.

Discussions about this issue are complex because the conversations are made in the shadow of Paul's teaching on justification. ${ }^{3}$ When Paul's

1 See Dale C. Allison Jr., A Critical and Exegetical Commentary on the Epistle of James, ICC (New York: T \& T Clark, 2013), 434-438.

2 Cf. J. Pelikan and V. Hotchkiss, eds., Creeds and Confessions of Faith in the Christian Tradition Vol. III Part V: Statements of Faith in Modern Christianity (New Haven: Yale University Press, 2003), 877-888.

3 Cf. C. Burchard. Der Jakobusbrief, HNT 15.1 (Tübingen: Mohr Siebeck, 2000), 18-20; Allison Jr., 
teaching that is concerned with the relationship between true faith and "works of the law" is used to read the concept of faith in LOJ," scholars tend to understand Paul and James as diametrical opposites. Similarly, the concept of faith in LOJ tends to be read as if it was written to deal with the same issues and the same questions faced by the recipients of Paul's letters; ${ }^{5}$ as a result, many scholarsbelieve that James disagreed with Paul and attacked "Pauline doctrine." 6 Although the issue of "works of the law" (namely, circumcision, kashrut and Sabbath-observance) was probably faced generally by Jewish people in Judea and beyond that area (cf. 1 Mc 1. 15, Ant 20. 45-46; Gal 2. 11-15), no evidence indicates that these laws are the problems in the community that LOJ addresses, and therefore, it is not fair to force LOJ to speak beyond its context.

At the same time, although understanding the historical context of LOJ is important, it is enigmatic. The historical approach used to analyze the letter leads many scholars to believe that it is pseudephigraphy, ${ }^{7}$ and NT scholars disagree about the time when the letter was written (though scholars usually propose the letter's date to be within the time frame of 40 $\mathrm{AD}$ to the late 2 nd century $\mathrm{AD}$ ). Reasons used to argue for a later date are based primarily on the late acceptance of the letter in the NT canon. ${ }^{8}$ However, this is an argument from silence, and, thus, it is highly subjective

\footnotetext{
The Epistle of James, 426-441.

4 For a discussion of Paul and the law, see James D. G. Dunn, ed., Paul and the Mosaic Law, WUNT 89 (Tübingen: Mohr Siebeck, 1996).

5 See also R. Bauckham, James: Wisdom of James, Disciple of Jesus the Sage (London: Routledge, 1999), 113-140; Luke T. Johnson, Brother of Jesus, Friend of God: Studies in the Letter of James (Grand Rapids: Eerdmans, 2004), 10-17.

6 See, e.g., W. Popkes, "The Mission of James in His Time," in The Brother of Jesus: James the Just and His Mission, edited by B. Chilton and J. Neusner (Louisville: Westminster, 2001), 8892;Dieter Lührmann, "Faith," in The Anchor Bible Dictionary Vol. 2, edited by D. N. Freedman (New York: Doubleday, 1992), 756.

7 See, e.g., M. Konradt, "Jakobus, der Gerechte," in Pseudepigraphie und Verfasserfiktion in frühchristlichen Briefen, WUNT 246, edited by Jörg Frey et al. (Tübingen: Mohr, 2009), 275-297.

8 Cf. Johnson, Brother of Jesus, 45-100.
} 
and debatable to place $\mathrm{LOJ}$ at the late period (that is, the second century AD). In addition, second century church traditions--especially 1 Clement; see, e.g., $1 \mathrm{Cl} 12.1$-- indicate that they knew the letter. ${ }^{9}$

As a result, another angle needs to be used to discover the context of LOJ, and the literary (synchronic) approach could make some contribution to illuminating this issue. The theory behind this approach postulates that the text functions "as a mirror, so as to derive meaning from within the text itself."10 Indeed, the text basically creates its own context, the literary context, and this context could reflect the historical context in which the text was written. To apply this approach, interpreters need to treat the text as a discourse in which every unit of the text is considered as having its own function and is interconnected with the other units, synergistically creating a literary context and a singular means of communication.

This approach will be used in present study to observe the meaning and the function of the concept of faith in LOJ. Some questions need to be addressed in this article, such as: how does LOJ use the concept of faith in light of its literary context? How does LOJ describe the meaning of faith in its literary context? And how does the literary context of LOJ give some indication regarding its historical context and audience?

The combination of the method of semantic field analysis and discourse analysis could shed some light to the questions above. While the first method will analyze ranges of meanings for the word "faith" in various contexts, the other will observe the meaning of faith in light of the micro and macro structures of LOJ. ${ }^{11}$ To apply the method, some analyses will need to be employed, namely, grammatical analysis, constituent analysis, analysis of unit boundaries, analysis of interrelatedness units, and analysis of the means

\footnotetext{
9 See Johnson, Brother of Jesus, 45-100.

10 See David R. Bauer, "Literary Interpretation, NT," in The New Interpreter's Dictionary of the Bible Vol. 3, edited by K. D. Sakenfeld (Nashville: Abingdon, 2008), 672.

11 For a helpful discussion of discourse analysis, see Stanley E. Porter and D. A. Carson, eds., Discourse Analysis and Other Topics in Biblical Greek (Sheffield: Sheffield Academic, 1995), 14-116.
} 
of discourse.

\section{The Concept of Faith in Light of Semantic Field Analysis}

Becker and Michel find that two Greek words (and their cognates) are

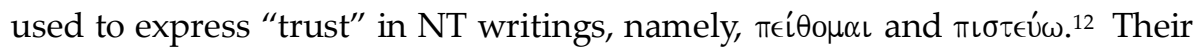
analysis show that both words are used to express a personal relationship built on the basis of trust. The difference between $\pi \epsilon i \theta o \mu \alpha \iota$ and $\pi\llcorner\sigma \tau \epsilon u ́ \omega$, is that while the first is used to show the relationship that comes about "through persuasion and conviction," the other is used to express a "faithful relationship" built on "an agreement and trustworthiness of the promise."

Similarly, Louw and Nida analyze the word "faith," but their observation was employed in light of Semantic Domains, which leads them to the conclusion that the word "faith" is used in the domain of "Hold a View, Believe and Trust."13 Furthermore, they also recognize that the word is used in two semantic fields: "trust and rely" and "be a believer and Christian faith." The second semantic field consists of technical words used to speak about Christian faith.

Based on the Louw and Nida's work, we can identify the following Greek words used in the semantic field of "faith" in LOJ, namely, (i) $\pi \epsilon i \theta \omega$

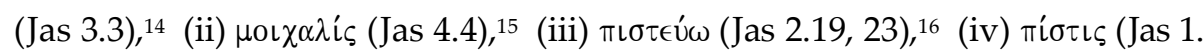

12 O. Becker and O. Michel, "Faith," in The New International Dictionary of New Testament Theology, edited by Colin Brown (Exeter: Paternoster, 1975), 587-606.

13 J. P. Louw and E. A. Nida, Greek-English Lexicon of the New Testament Based on Semantic Domains Vol. 1 (New York: UBS, 1989), 365-379.

14 According to Louw and Nida, Greek-English Lexicon 376, the word mei $\theta \omega\llcorner\sigma$ is used to express the act of believing "in something or someone to the extent of placing reliance or trust in or on." In the Catholic Epistles, this word is used twice (i.e., Jas 3.3 and 1 Jn 3.19).

15 Louw and Nida, Greek-English Lexicon 378, explain that the word $\mu \circ\llcorner\chi \alpha \lambda i$ is is used to indicate one who is "being unfaithful to one's earlier and true beliefs."

16 Louw and Nida, Greek-English Lexicon 376-379, find that the word pisteu,w in NT writings is used in two semantic fields; it could be used as the act of believing to "the extent of complete trust and reliance" and the act of believing in "the good news about Jesus Christ and to become

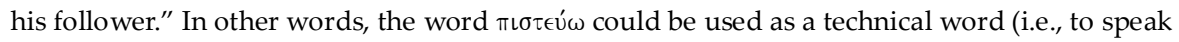
about the act of believing in Christ) or it is used as a non-technical word. 


\section{$3,6 ; 2.1,5,14,17,18,20,22,24,26,5.15) \cdot{ }^{17}$}

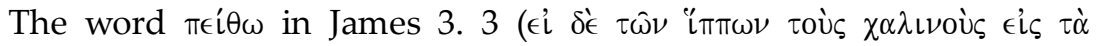

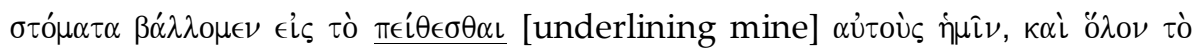
$\sigma \hat{\omega} \mu \alpha \alpha \dot{U} \tau \hat{\omega} \nu \mu \epsilon \tau \dot{\alpha} \gamma o \mu \epsilon \nu)$ does not refer to "an act of believing" because the context does not support this meaning.

The word $\mu$ oเ $\chi \alpha \lambda i \varsigma$ in NT writings is used seven times (Mt 12. 39, 16. 4; Mk 8. 38; Rom 7. 3 [used twice]; Jas 4. 4; 2 Pt 2. 14); the context shows that LOJ used the word $\mu$ oเ $\chi \alpha \lambda i \iota_{\varsigma}$ closely to Jesus' traditions rather than to Paul

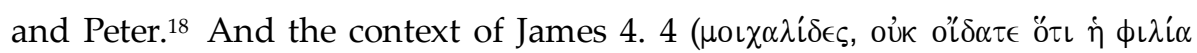

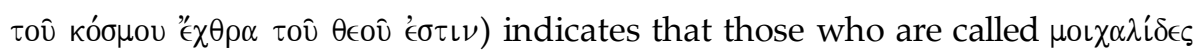
those who are referred to evil people described in James 4. 1-3 and the hearers of LOJ. This implies that some individuals in the community of believers were unfaithful and disobeyed God's will. ${ }^{19}$

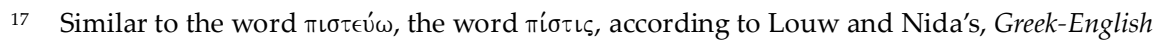
Lexicon 376-379, investigation, is also used in two semantic fields. In the context of semantic

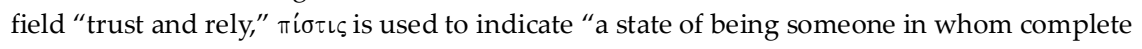
confidence can be placed." In contrast, in the context of semantic field "be believers and Christian belief," it refers to (i) the belief in Christ that empowers and makes someone "to become a believer," (ii) "Christian faith," and (iii) "the content of what the Christians believe." 18 While Paul and Peter use the word $\mu \circ\llcorner\chi \alpha \lambda i c$ in the context of a husband-wife relationship, Jesus' tradition uses the word in the context of covenantal relationship. James 4.4 clearly uses the word $\mu \mathrm{o} \chi \alpha \lambda i i_{\zeta}$ in the second context. The author of LOJ rebukes the hearers because of their friendship with the world, and Luke T. Johnson correctly shows that friendship in that times "involved 'sharing all things' in a unity both spiritual and physical." The Letter of James: A New Translation with Introduction and Commentary, AB 37A (New York: Doubleday, 1995), 279.

19 Peter H. Davids, The Epistle of James: A Commentary on the Greek Text, NIGTC (Exeter:

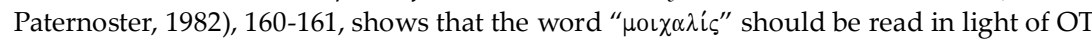
background. This word is used to speak about Israel described as God's unfaithful wife. Furthermore, he emphasizes that, in the biblical context, the word is only applied to Jewish people who claim that they "have a covenantal relationship with Yahweh." If Davids is correct, it shows that LOJ was sent to Jewish believers. In addition, the plural vocative form used in this word does not indicate that all of the hearers of LOJ are accused as unfaithful; based on the comparison to the Qumran literature, Davids argues that the plural form is used to refer to individuals who "separate themselves from the church and from God." This could imply that some believers have become apostates, but it is also possible to understand this strong word as a firm warning to some unfaithful and disobedient believers to compel their s repentance and protect them from apostasy. 
Furthermore, the use of words $\pi\llcorner\sigma \tau \epsilon u ́ \omega$ and $\pi\llcorner\sigma \tau \iota \varsigma$ in LOJ is intriguing; while both words in the NT writings are used many times, the author seems

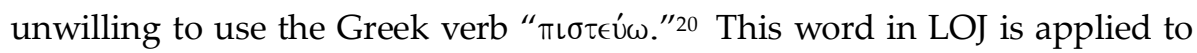
Abraham's trust (Jas 2. 23) and believers' confession of faith (2. 19), but it is also used for demons. In other words, the author of LOJ does not use the word $\pi\llcorner\sigma \tau \epsilon \dot{\omega} \omega$ as the technical term to refer to Christian belief or the act of believing in Christ; instead, it could be used to refer to one's genuine trust in God or as the act of confessing a faith (a statement of faith).

Similarly, the uses of the word "$\pi i \sigma \tau \iota \varsigma^{\prime}$ " in LOJ are also complex; although the author used it as the technical term to speak about "the true faith in Christ" (cf. Jas 2.5), it is also used to speak about a faith that is only a claim or a statement (cf. Jas 2. 14).

Thus, while the main words used to speak about faith in LOJ are $\pi\llcorner\sigma \tau \in \dot{\omega} \omega$ and $\pi i \sigma \tau \iota \varsigma$, the author of LOJ used the concept of faith with multiple meanings. It is also important to notice that although the word "faith" is mostly used in James 2, this does not mean that the concept of faith in this letter existed only in some limited units (i.e., Jas 1, 2, and 5). McCartney observes the structure and theme of LOJ and concludes: “... the overall theme of James, the matter that occurs not just at the beginning and the end but throughout, and that drives the deep concerns of the whole letter, is that genuine faith in God must be evident in life"; although the word of 'faith' is not used throughout [LOJ], according to McCartney, "it lies at the root of the

20 In NT writings the verb " $\pi\llcorner\sigma \tau \epsilon u \omega \omega "$ is used around 71 times in the Synoptic Gospels and Acts, 98 times in the Gospel of John, 54 times in Paul's letters (including the Pastoral Epistles), twice in James, three times in 1 Peter, 9 times in 1 John and once in Jude. It is not clear why the verb

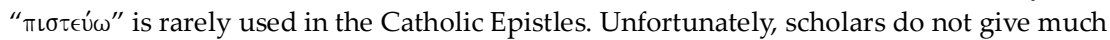
attention to this issue. It could be that LOJ rarely uses the verb " $\pi\llcorner\sigma \tau \epsilon u ́ \omega "$ because it does not mainly deal with soteriological issues (unlike the letters of Paul and the Gospel of John), in which the concept of "believing in Christ" is crucial and fundamental; LOJ mostly deals with the pastoral issue, in which "faith" in the community of believers tends to be only a statement or a confession. 
whole James's exhortation."21 Therefore, the concept of faith in LOJ should be understood in a broader context. And the following discussion will try to track the meaning of "faith" in LOJ; it will begin with the micro-structure analysis and will end with a discussion on the macro-structure of LOJ. Three units in which the word "faith" used in James 1 and 2 (i.e., Jas 1.3, 6; Jas 2.1, 5; and Jas 2.14-26) will be analyzed next to observe the meaning of the word "faith" in LOJ; then a discussion about the macro structure of LOJ will be employed to connect the result of previous analysis to the whole structure of LOJ that has been proposed by other scholars.

\section{The Concept of Faith in James 1.3, 6}

After introducing himself, 22 the author of LOJ speaks about various testing/trials that probably will be faced by believers. ${ }^{23}$ He orders his hearers to think about the ultimate joy as they face sufferings ( $\pi \epsilon \iota \rho \alpha \sigma \mu o \hat{\iota} \varsigma$ ) because

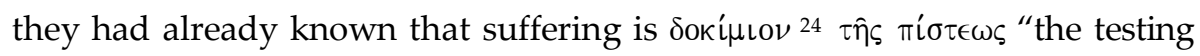
of faith" and will produce steadfastness. Even so, what is the meaning of

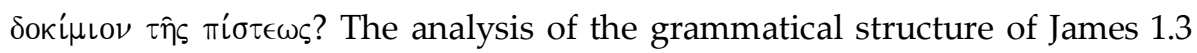
could answer this question.

21 Dan McCartney, James, BECNT (Grand Rapids: Baker, 2009), 57.

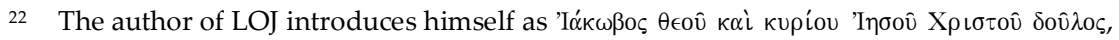
"James a servant of God and Lord Jesus Christ." Although the author does not give much information about himself, it is clear that he is a person who is known well in the early church. 23 Some scholars argue (for instance, McCartney, James, 85) that the word "peirasmoi/j" in this unit should be translated as "testing." This suggestion is based on the reason that the word in LOJ has double meanings: "testing" and "temptation." In the context of James 1.2-3, the word apparently is used to speak about "testing" rather than "temptation."

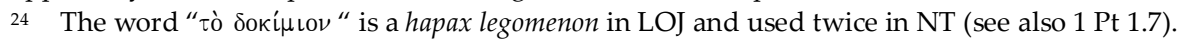


C. 1.2

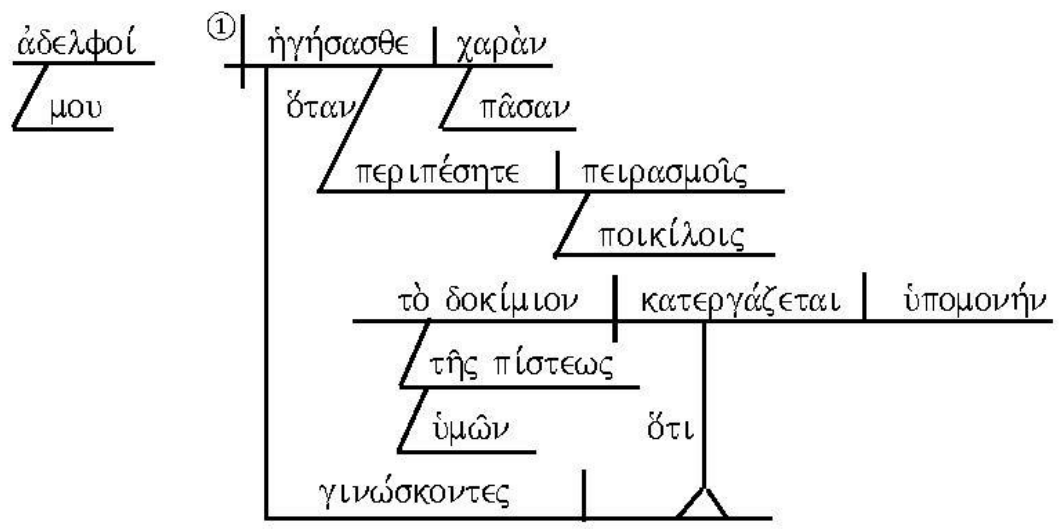

This diagram shows that (i) James 1.2 and James 1.3 are one unit, (ii) the sentence $\Pi \tilde{\alpha} \sigma \alpha \nu \chi \alpha \rho \dot{\alpha} \nu \dot{\eta} \gamma \dot{\gamma} \sigma \alpha \sigma \theta \varepsilon$ functions as the main clause in this cola, and the other clauses support this main ide, 25 (iii) the word "faith" is used in the supporting clause: "knowing that the testing of your faith ( $\tau \tilde{\eta} \varsigma \tau \tilde{\eta} \varsigma \pi i \sigma \tau \varepsilon \omega \varsigma$ )

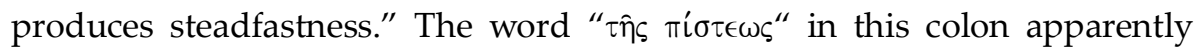
uses the genitive of description; and therefore, syntactically, the word functions to describe the testing faced by the hearers as the testing of faith.

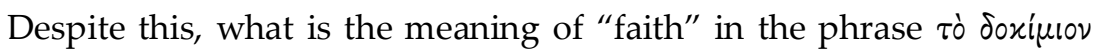
ن $\mu \tilde{\omega} \nu \tau \tilde{\eta} \varsigma \pi i \sigma \tau \varepsilon \omega \varsigma$ ? The semantic field analysis above, on the word "faith," has shown that " $\pi i \sigma \tau \iota \varsigma$ " could be used to express "a trustworthy condition of someone" or "a belief that is held by believers." So, there are two

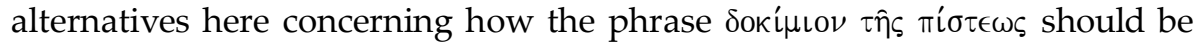
understood: the testing used to test the believers' trustworthy condition or to test the belief of the believers.

Before deciding which meaning of faith is the most possible in this colon, interpreters should consider the literary context of the suffering in

25 A discourse contains several basic elements: a word (the smallest part of a discourse), a phrase, a colon (i.e., a simple or complex sentence) or a cola (i.e., a compound sentence), an unit, a paragraph, a text (discourse). In this work, the symbol (1), (2), and so forth are used to indicate a colon in a cola or in a unit. The code "C.1.2" means cola 1.2. Further discussion of colon analysis, see J. P. Louw, Semantics of New Testament Greek (Atlanta: Scholars, 1982), 95-96. 
LOJ, particularly in James 1. James 1. 6-8 indicates that the testing (i.e., suffering) faced by believers made some individuals doubt whether God is sovereign in their lives. ${ }^{26}$ This literary context probably could lead interpreters to conclude that some individuals in the believing community had an inaccurate understanding about God. These individuals doubted God's sovereignty because they refused to live in accordance with true belief. ${ }^{27}$ Hence, the problem does not lay in their belief but on the unwillingness to commit one's life to true belief. In this context, God allows adversities to strike the lives of believers to show them whether they truly trust him or not.Similarly, in James 1. 13-14, the author makes a correction because apparently some individuals in the believing community have become bitter about God's role in their suffering; again, the literary context of James 1 indicates that some individuals in the community failed to live in accord with their belief, and as a result, they blamed God for their trials.

In addition, analysis of unit boundaries could show that there is an "anacoluthon" 28 between James 1. 2-4 and 1. 5-8; the author of LOJ changes

26 Cf. McCartney, James, 85. Comparing to Matthew 7.7 and 21.21-22, there is a possibility that James 1.5-8 and the Gospel of Matthew share similar traditions. Although it is possible that the author of LOJ used Jesus tradition, this does not mean that the author of LOJ used a tradition similar to Matthew. Therefore, the meaning of faith in James 1.6 should be seen primarily in light of the literary context of James 1 . We will leave this discussion aside because discourse analysis is not designed to focus on redactional issues.

27 Davids (The Epistle of James, 73) argues that the doubter in James 1.6-8 does not refer to believers whose faith is weak because of facing so many sufferings, but it refers to those who distrust God. Similarly, Scot McKnight finds that the doubter refers to those who are "doubleminded," and with respect to OT traditions, this metaphor refers to individuals who are unfaithful to God's covenantal relationship, who refuse to obey God's will (i.e., caring for the poor and helpless) and who do not wholeheartedly love God. The Letter of James, NICNT (Grand Rapids: Eerdmans, 2011), 91-92.

28 E. W. Bullinger (Figures of Speech Used in the Bible [Grand Rapids: Baker, 1968], 720) defines "anacoluthon" as a figure of speech used to indicate "a breaking off the sequence of thought."However, the author of LOJ does not use this literary style to break off his conversation but to change the focus of discussion. In James 1.2-4, the author of LOJ speaks generally about the sufferings faced by believers, and in James 1.5-8 he directs the discussion to more specific subjects, like the one regarding some individuals who have weak faith and those who refuse to embrace true faith. 
the "actor" and the "subject" in the conversation from the second plural form (referring to the believers) to the third singular form (referring to any given individual in the believing community). In this case; apparently the author wants to focus his conversation on some details. In James 1. 5-8, he actually talks about two different individuals, specifically, one who needs to ask for wisdom because he probably does not know how to integrate his belief into daily life-particularly when he faces suffering (Jas 1. 5-6a) - and one who is described as "double-minded" (Jas 1. 6b-8). Although it is possible to argue that an individual who lacks wisdom and is a "double minded" person is hypothetical, it is also possible that these hypothetical individuals reflect real people in the believing community. In other words, the two types of individuals described in 1. 5-8 could mirror an actual typifying of believers, that is, those who face suffering and keep believing in God and those who have a weak faith or are double-minded, a sign of a false believer. In this context, the author believes that suffering will not only refine the quality of the believers' lives (to help believers live consistently according to their belief), but it also will refine the community of believers (separating true believers from inauthentic ones). While this testing will lead true believers to perfection, it also will uncover fake Christians.

Therefore, the concept of faith in James 1. 2-3 should be understood as the belief in God that empowers and makes believers to submit absolutely to God's will. The test of faith in this sense means the test that will refine believers to live in accord with their belief. And the result of this process is perfection.

What is the function of this concept of faith in the macro structure of James 1 ? Constituent analysis will answer the question. 


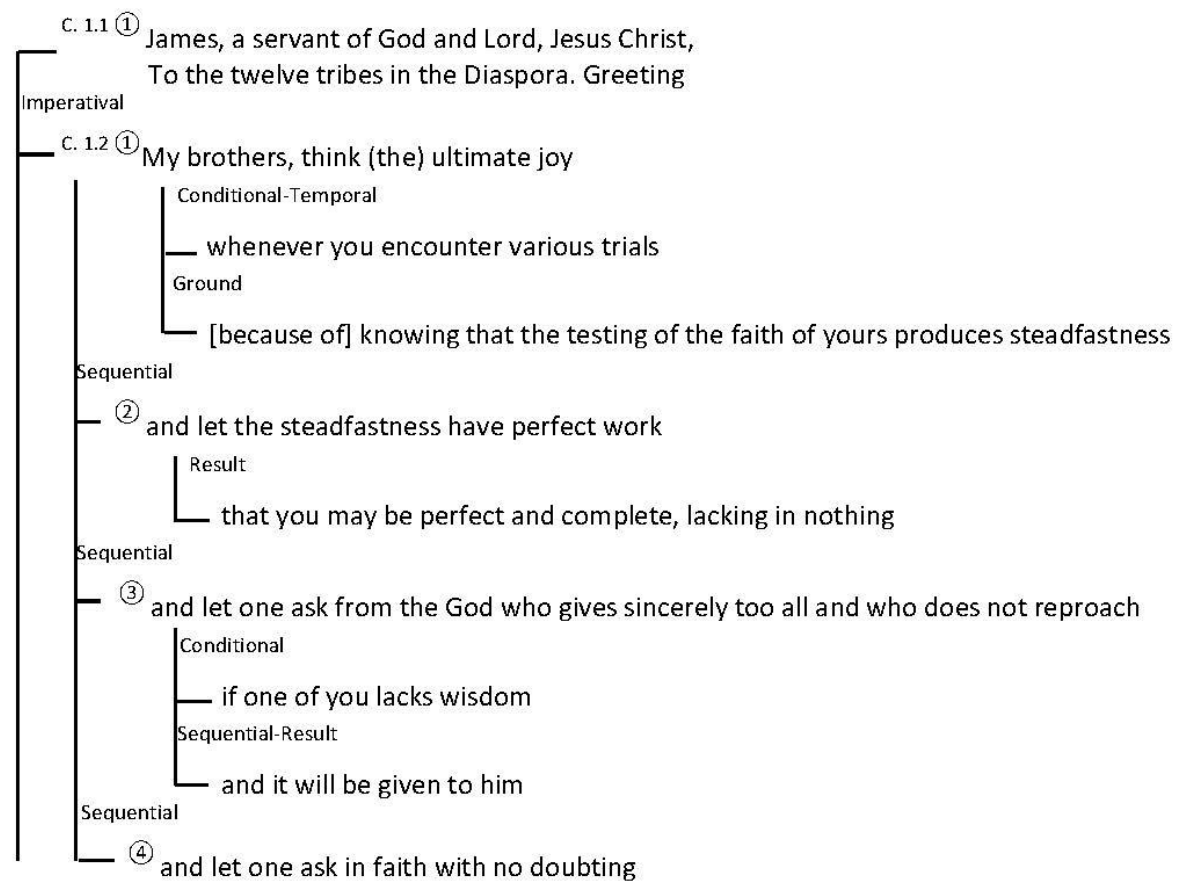

Constituent analysis shows that the concept of faith in cola 1.2 (Jas 1. 2-3) functions as "the ground. "The "ground" is used to emphasize the reason that exists behind the main argumentation, and the main argumentation in Jas 1. 2-3 is the instruction to "think the ultimate joy." It means that the author of LOJ bases his order (i் $\gamma \sigma \alpha \alpha \sigma \theta \epsilon \chi \alpha \rho \dot{\alpha} \nu)$ on the reason ( $\gamma \iota \nu \omega ́ \sigma \kappa \nu \tau \epsilon \varsigma$ "because of knowing") that believers had already known the

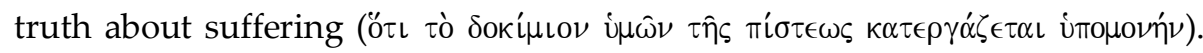

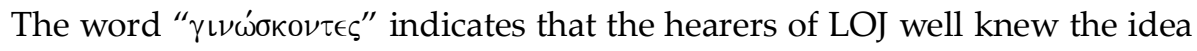

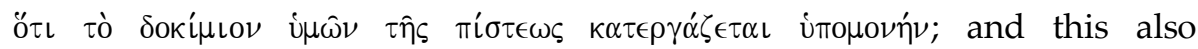
indicates that the idea is probably a kind of tradition that was familiar and known among believers. Similar vocabulary used in James 1. 2-4, 1 Peter 1. 67, and Romans 5. 2-5 supports this indication;29 taking into account this

29 Cf. Davids, The Epistle of James, 66. Although it is not clear for modern readers which 
constituent analysis, the author basically attempts to ask his hearers to live in accord with the tradition which they had already known. In other words, the concept of faith in this unit is used to anticipate a lot of sufferings that believers could probably face in the future, and the author of LOJ asks his hearers to make their live consistently with their beliefs.

\section{The Concept of Faith in James 1.6}

The constituent analysis above shows that there is sequential train of thought between James 1. 2-3 and James 1. 6-8 (the word "faith" is also used in this unit). Before discussing the relation between James 1. 2-3 and James 1. 6-8, it will be helpful to discuss firstly the meaning of faith in James 1. 6-8.

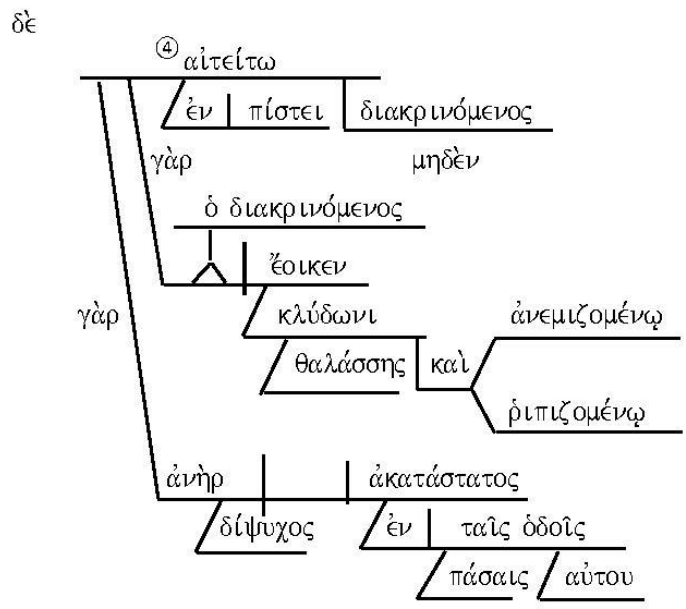

idea/tradition is meant by the author of LOJ and his hearers, LOJ indicates that (i) the tradition is probably related to sufferings that are various, (ii) the tradition apparently emphasizes the final result of sufferings that is good, and (iii) the tradition is talking about a testing/suffering that is familiar and known well by the hearers. Some scholars propose that the tradition is rooted in the Jesus tradition in Mt 5.11-12. Notwithstanding this may be the case, there are other possibilities that are worthy of some consideration. First, there is the possibility that the tradition used by James comes from the tradition of Job. Since the influence of the wisdom tradition in LOJ is strong and the story of Job in this letter also gets some attention, and since the suffering of Job could match with the content of the tradition in James 1.3, it is still possible to propose the tradition of Job as a candidate for the tradition behind this unit. Second, there is a possibility that the tradition used by James comes from Jesus' teaching regarding sufferings that will be faced by believers in catastrophic events. 
The syntax structure of this unit shows that there are one main clause and two supporting ideas in James 1. 6, 8, and the word "faith" is used in the

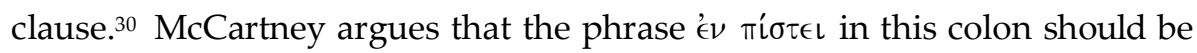
understood as "a trust in the character and promises of God"; he also says that this faith is related to total commitment to God. ${ }^{31}$ Similarly, Davids argues that the background of this command is related to some individuals who distrust God. ${ }^{32}$ Both McCartney and Davids recognize that the wisdom tradition could have influenced James in this issue; Davids, for example, shows that Sirach 33. 1-3 uses a similar metaphor (that is, one who is unfaithful is like a boat in the midst of a storm). ${ }^{33}$ Nonetheless, why is the issue regarding the doubter discussed here? The theme of "the doubter or the double minded" in James 1 functions as a ground; in fact, the author of LOJ uses a double ground here to emphasize that this issue is substantial. McCartney is probably correct when he accentuates that "James speaks so harshly of the doubter precisely because faith is so important. ${ }^{34}$ Faith is the grounding that prevents one from being tossed around like asea billow ... And without faith, one's life is chaotic, without direction or moral compass."

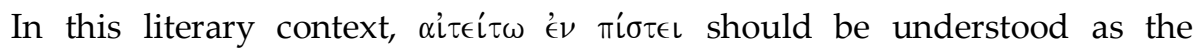
opposite condition of the doubter; therefore, if the doubter cannot be trusted because he is double-minded, a believer who asks in faith refers to one who

\footnotetext{
30 James 1.2-8 has four colons: James 1.2-3 (colon (1), 1.4 (colon (2), 1.5 (colon (3), and 1.6, 8 (colon (4).

31 McCartney, James, 90.

32 Davids, Epistle of James, 73-74.

33 According to P. W. Skehan and A. A. Di Lella, The Wisdom of Ben Sira, The Anchor Bible 39 (New York: Doubleday, 1987), 398-399, one who fears of the Lord in this text refers to those who keep the law (32.24a) and trust in the Lord (32.24b). These people are truly wise and will survive and persevere with patient endurance although they have to face many trials in their lives. In contrast, those who do not fear the Lord are like a boat in the midst of a raging storm. Moreover, they also conclude that these verses have a main point underscoring that "for the faithful who observe the law perfectly the Lord will fulfill all his promises contained in the law."

34 McCartney, James, 92.
} 
has "a state of being in whom complete confidencecan be placed." But it is important to notice that in LOJ, those who have that state of being refer to those who have a right belief and are committed to live in accord with their belief.

The sequential train of thought links not only James 1. 2-3 and 1. 6-8, but it also connects $1.1,35$ 1. 2-3, 1. 4, 1. 5, 1. 6-8, and 1. 9-11.36 This continual train of thought reaches its climax in $1.12 .{ }^{37}$ Although the grammatical analysis and the constituent analysis employed to this unit will show that cola 1.4 (James 1.4) is independent, the analysis of unit boundaries reveals that the cola are related closely to the previous one. This analysis shows that there are semantic references that bind these units. Further, Bullinger identifies "repeated anadiplosis" in these cola; ${ }^{38}$ this figure of speech is used to

35 In discourse analysis, every unit is seen as being interconnected with the others. From this perspective, cola 1.1, James 1.1 (salutation/introduction), should be seen as a part of unit 1 (Jas 1.1-15), but this raises a question: what is the function of cola 1.1 within its unit? Although grammatical analysis and analysis of unit boundaries (see recognize that cola 1.1 are independent, constituent analysis shows that it is related to the next cola. In fact, it has an

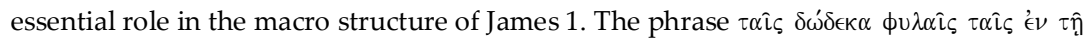
$\delta\llcorner\alpha \sigma \pi \circ \rho \alpha$, used to identify the hearers of LOJ, could have a triple meaning. On one hand, it refers to Jewish believers who lived in a location called "diaspora"; it is also could be used to speak about the condition of suffering that is experienced by God's people (cf. McCartney, James, 194). On the other hand, it could be indicating the character of the believing community as an eschatological movement who strongly hope and wait for the restoration time (for further discussion on this issue, see Allison Jr., The Epistle of James, 127-133). Although many scholars, such as Allison Jr, doubt whether the word "diaspora" could be understood as a condition of suffering, this meaning is closely related to the issue in James 1.2-3 and it connects James 1.2 and James 2.2. In other words, before the author of LOJ gives the instruction to think of ultimate joy ( $\pi \hat{\alpha} \sigma \alpha \nu \chi \alpha \rho \dot{\alpha} \nu \dot{\eta} \gamma \eta \dot{\eta} \sigma \alpha \sigma \theta \epsilon)$, he has already mentioned the reason why he ordered this (Jas 1.1), namely, namely, because the hearers were living in the diaspora, in conditions of suffering, and in the waiting period for the restoration of Israel.

36 Syntax analysis shows the coordinate conjunction de. is used to connect James 1.2-3, 1.4, 1.5, $1.6-8,1.9$, and 1.10-11. Syntax analysis and constituent analysis position James 1.7 differently; while the first analysis puts these cola as the independent unit, the second analysis recognizes it as a part of cola 1.6-8.

37 Interestingly, cola 1.12 repeat the theme of sufferings, which is the main theme in cola 1.2-3. This "inclusio" could indicate that the sufferings are the main issue in these units. This also means that the concept of faith is strongly correlated with the condition of suffering.

38 Figures of Speech, 259: ... that your testing of faith produces steadfastness but let The steadfastness has perfect work that you may be perfect and complete, lack in nothing 
create a climactic structure within a sequential sentence. In addition, in the case of James 1.2-4, the climax idea in this unit is the perfection. In other words, the author of LOJ highlights, especially in these cola, that the end of testing is perfection. ${ }^{39}$ In the next cola, the author of LOJ shows how believers can reach perfection notwithstanding their difficult trials. In cola 58, the author of LOJ draws attention to the fact that the believers need to test themselves to see if they truly believe in God. This is an important aspect in the believers' lives because without truefaith, it is useless to ask for God's wisdom. This is the reason why the author of LOJ enjoins his hearers to "ask wisdom in faith." Wisdom cannot answer all questions about human suffering. Instead, it is true faith that enables believers to live in suffering, their having confidence in God not with standing their lack of understanding his specific purposes for their adversity. Therefore, the function of wisdom in LOJ is mainly to help believers integrating their belief in real life issues; wisdom is not used to solve the mysteries of human life, but it helps believers to obey God's will in their daily life.

How should James 1.2-3, 6-8 be understood in the macro structure of James 1? Analysis of interrelated units (see the following chart) could help to understand the relationship between each unit in James 1 .

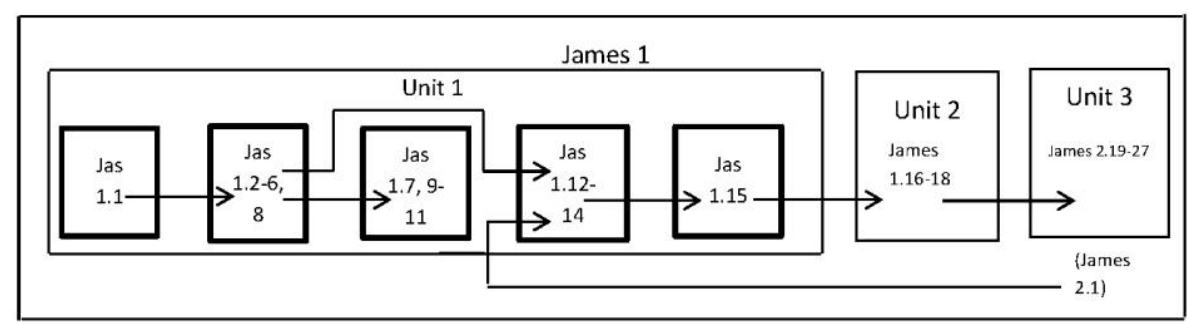

The syntax and constituent analyses of James 1 show that the text consists of three units. Unit 1 (Jas 1.1-15) emphasizes "the order to think joy

39 For a detailed discussion of the issue on perfection in LOJ, see McKnight, The Letter of James, 80-82. 
when believers face sufferings," unit 2 (Jas 1.16-18) emphasizes "the order to have a correct understanding regarding God's role in human temptation," and unit 3 (Jas 1.19-27) emphasizes "the order to have correct understanding on how to live in God's will." The relation between units 1 and 2 is not difficult to understand; unit 2 becomes the principle in understanding the suffering faced by believers. The connection between units 2 and 3 is more complicated. While the main theme in unit 3 is related to "the order to live in accord with God's will," the unit ends by stressing the importance of caring for, as an act of authentic love and faith, orphans and widows (Jas 1.26-27). If the idea about orphans and widows in this unit has a function as the example used to show who those are suffers, then the link between units 1, 2, and 3 becomes clear and understandable. While unit 1 is used to call believers to think joy when they face the sufferings and while unit 2 is used to call believers to have the correct understanding of God, in unit 3, the author of LOJ calls believers to live in absolute submission to God's will by loving those who suffer the most, like orphans and widows. In other words, based on the macro structure of James 1, the author of LOJ puts the understanding of God as the central point to understand our own sufferings and others. ${ }^{40}$ The author of LOJ also reiterates that it is true faith and God's wisdom that enable believers to face their own suffering in light of God's perspective, and it is also true faith and God's wisdom that compel believers to have empathy, care, and love when they see the suffering of others.

\section{The Concept of Faith in James 2.1, 5}

The concept of faith in James 2 is highlighted in James 2.1, 2.5 and 2.14-26. This section will focus on discussing James 2.1 and 2.5 , the next

\footnotetext{
40 This perspective is the character of the wisdom tradition in which the sufferings are seen from God's perspective, and LOJ heightens the significance of true faith that will help believers to understand sufferings based on God's perspective so that they will be able to face difficulties without abandoning their trust in God.
} 
section on James 2.14-26. Although the syntactical structure of these units is independent, both units still are semantically related; both units basically speak about the poor but from different angles.

\section{The Concept of Faith in James 2.1}

The syntax structure of James 2.1 can be illustrated in the following diagram.

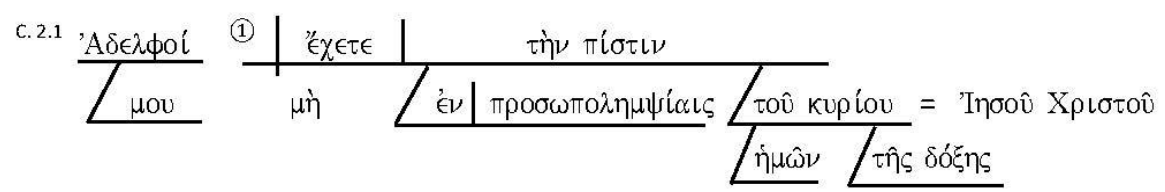

The concept of faith in this cola is related to the believer's belief in Christ. The second plural verb (' $€ \chi \in \tau \epsilon)^{41}$ used in this colon indicates that the author is speaking directly to his hearers. While true belief in Christ should contain confession, trust, and obedience, the author of LOJ in this colon apparently deals with the problem of faith of some individuals in the community for whom it becomes only a matter of confession. This is the reason why he instructs his hearers to have a faith without favoritism because true faith does not lead to the preferential treatment of others. ${ }^{42}$ Davids argues that this colon should be interpreted from an eschatological

41 The imperative form used here is only found twice (cf. 2.18). There is a possibility that both units are interconnected (cf. McKnight, The Letter of James, 175); the issue of favoritism could be the background and the context of James's teaching on faith in James 2.18. The author of LOJ apparently believes that his hearers had faith in Christ, but, at the same time, he also shows that these believers were exercising partiality. This is the ironic condition that should not happen in the believing community.

42 OT writings also speak about the issue of partiality. For example, Proverb 18.5 says, "It is not good to be partial to a wicked man, or to deprive a righteous man of justice (RSV)." McKnight, The letter of James, 176 believes that Leviticus 19.15 ("You shall do no injustice in judgment; you shall not be partial to the poor or defer to the great, but in righteousness shall you judge your neighbor"-RSV) probably influenced the author of LOJ. There is also a possibility that Leviticus 19 also influenced James 5.9, 12, 20. 
perspective; ${ }^{43}$ the author of LOJ punctuates that those who believe in Christ will understand that the only person who is able and worthy to judge men is Christ; and, therefore, if they understand this, they should not show preference to anyone.

Why does the author of LOJ speak about this? Constituent analysis sheds some light on this inquiry.

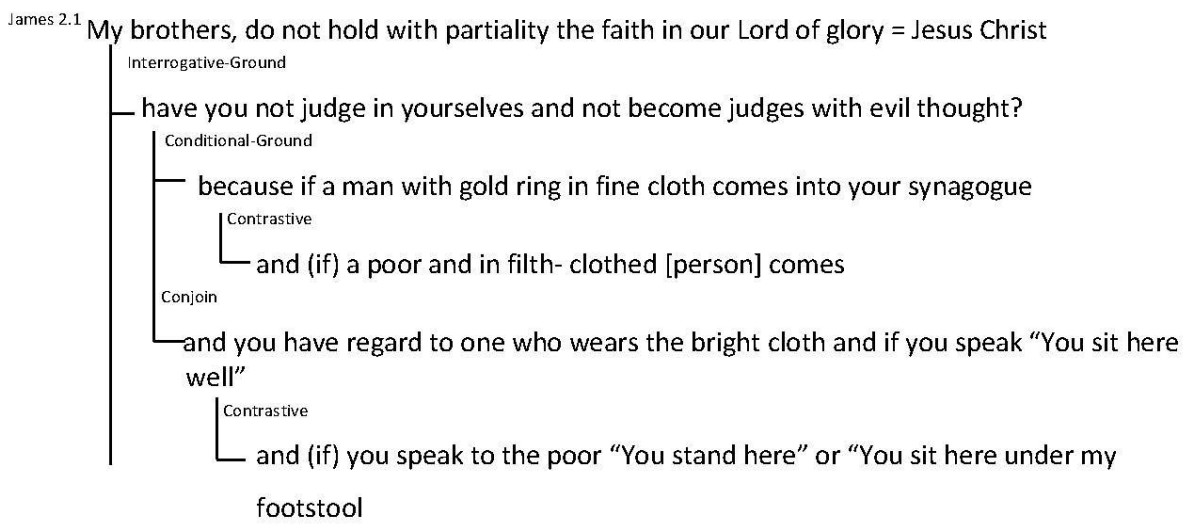

The analysis shows that the author of LOJ uses an interrogative form as a reason why he speaks about Christ and favoritism. ${ }^{44}$ The interrogative form can have many functions, like to elicit a response, as a means of persuasion, or, simply, to provoke thought. In this unit, the interrogative is used as a corrective to individuals who were showing favoritism amongst believers. At the same time, the analysis also shows that the rebuke is related

43 Davids, The Epistle of James, 107.

44 The author of LOJ seems to be making a play on words in this unit; he deliberately uses the

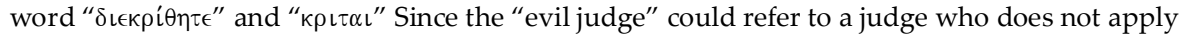
God's law in his court but uses the court for his own advantage, the author of LOJ uses the same image to show the problem of the believing community in which they did not care with God's will but were looking for advantages for themselves, and as the result they discriminated the weak (i.e., the poor). This is the background of the rhetorical question "have you not been judged in yourselves." Unfortunately, it is not clear whether the author of LOJ uses this question to make a rebuke or it is used to encourage the hearers to reflect deeply about what they have done to the poor so that they will not be like a wicked judge. 
to a hypothetical example (as has been discussed before, this hypothetical situation could also reflect a real situation within the believing community. ${ }^{45}$ The most important element in this example is the mention of some hypothetical believers who despise the poor. In other words, the author of LOJ shows that it is ironic that the same lips used to confess faith are also used to despise the poor (cf. Jas 3.9). ${ }^{46}$

Although it is clear that the main issue behind the favoritism in the believing community is the failure to live in accord with true belief, there should be no excuse as to why some individuals would act in this way. However, there is an indication that some individuals live in partiality because they experience adversities. In James 2.6 rich people are described as acting violently toward believers, and this may have led some individuals to seek refuge within the believing community. They apparently found it in some rich people in their congregation, and then favoritism grew in the community because they tried to gain sympathy from the rich. This situation resulted in some individuals not only exhibiting favoritism toward the rich,

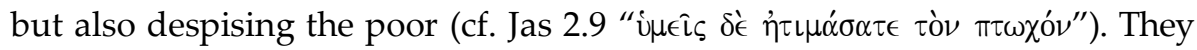
also did not trust their life in God anymore but trusted their life and hope in

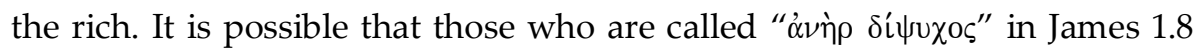

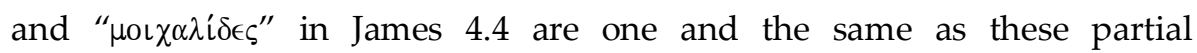
individuals.

This shows that James 2.1 and 2.2-3 are still related to the previous unitsin James 1, but how should the connection between the first unit of James 2 and units in James 1 be understood? McKnight believes that the

45 James calls the addresses as "synagogue." McKnight (The Letter of James, 183) argues that the word is used to refer to "the messianic community and learning center." If this interpretation is correct, the author of LOJ describes the casuistry of some individuals in the believing community. It would seem that a part of the community listened to instruction and verbally confessed their faith in Christ, but they failed not practice the faith that they claimed to have held; more clearly, they failed to integrate their faith with their actual lives.

46 McCartney shows that James 2.1-26 has a structure that is parallel to James 3.1-18. James, 65. 
author of LOJ apparently moves his general discussion (in Jas 1) to a more specific issue, specifically the issue of injustice in the messianic community (Jas 2). ${ }^{47}$ This analysis, however, ignores the evidence that LOJ has already spoken about the specific issue before in James 1.27 (i.e., visiting orphans and widows). To understand the connection between James 1 and 2, two aspects need to be considered. First, this unit should be understood as a sequential exposition from James 1.9-11. The previous analysis of interrelated units shows that unit 1.4 (Jas 1.9-11) is related to unit 4.1 (Jas 2.14); both units are about the poor and the rich. While the author in unit 1.4 shows that the poor are the blessed ones, he also points out how some individuals in the believing community despise them. ${ }^{48}$ In other words, the author of LOJ makes it a point to show that some individuals were living in direct contradiction to God's will; although they knew and confessed their faith in God, they did not practice what they professed, and LOJ sees this as a mark of disingenuous faith. Therefore, unit 2.1 (and also the other units in James 2) plays the role of reproving the hearers of LOJ who practiced disingenuous belief. Secondly, this unit should be understood as sequential teaching, continuing the instruction about true faith in James 1.2-3. The unit boundaries in James 1-2 shows that the word "faith" becomes the lexical reference that links James 1.2-3 and James 2.1. Equally important, the concept of faith is also mentioned in James 1 and 2; in fact, this concept is placed at the main units of both sequential instructions. Yet, the corrective form used in James 2.1 indicates that the unit has a different function from James 1; if the concept of faith in James 1 is used in a positive way (as an exhortation), in James 2, it is used in a more negative way (as a corrective), but both units are similar in content, that is, how believers could live in

\footnotetext{
47 McKnight, The Letter of James, 175.

48 Despising the poor is a serious issue in OT teaching; since God loves and stands for the poor, dishonoring the poor could be seen as dishonoring God. In contrast, showing mercy to the poor is seen as God's will; cf. P. J. Hartin, James, Sacra Pagina 14 (Collegeville: Liturgical, 2003), 70.
} 
accord with their belief.

\section{The Concept of Faith in James 2.5}

While the author of LOJ in James 2.1 focuses on the inconsistency of some believers when they show favoritism and despise the poor, in James 2.5-7 he speaks about God who is in favor to the poor. It seems that the author of LOJ uses the same pattern used in James 1.2-5 and 1.13-15 to deal with the problem of favoritism in the community. Similar to James 1.2-5 and 1.13-15, in which the author used God's perspective to address the issue of suffering, he also uses God's perspective to remedy the issue of the favoritism amongst believers. Syntax analysis will help to show how the author of LOJ tackles this concern and how the concept of faith is used here.

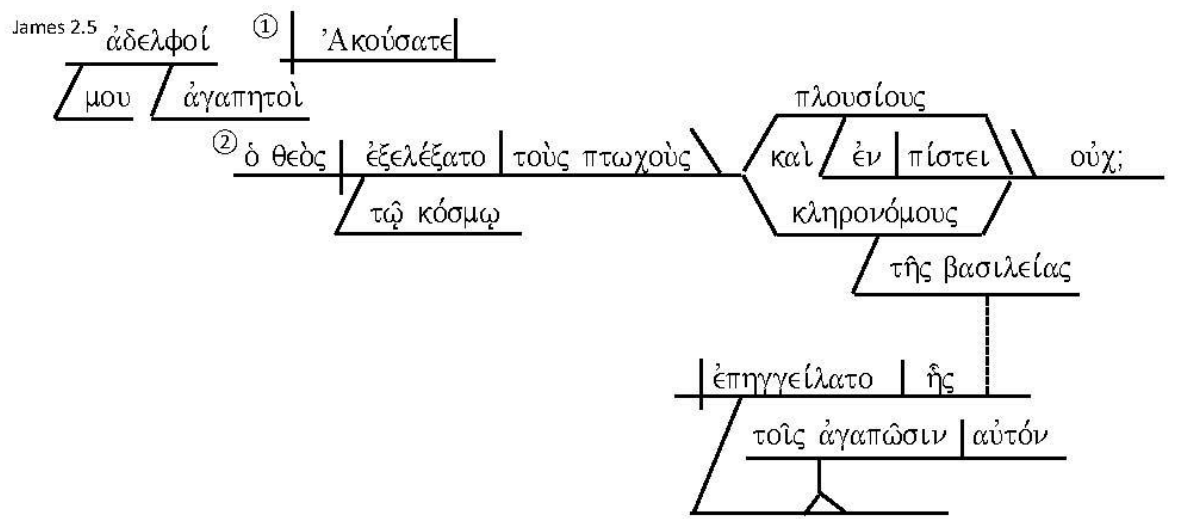

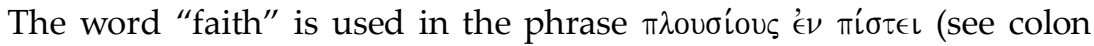
(2)).The proposition ' $\epsilon \nu$ in this phrase is probably used to reference a rich condition of the poor. This dative form is used to emphasize that the rich condition of the poor is not based on worldly prosperity but on faith. McKnight is convincing in saying that the meaning of "faith" in this phrase is used in opposition to the word $\tau \hat{\omega}$ кó $\mu \omega \omega .{ }^{49}$ At the same time, the word

49 McKnight, The Letter of James, 195 
"faith" needs to be understood in its relation to the poor. The concept of God's election of the poor and oppressed is rooted in OT traditions; the election of Israel is understood as God's election of the poor and oppressed. ${ }^{50}$ Therefore, the poor in the biblical tradition refers not only to those who are materially poor (and also in social condition), but it also refers to those who are pious. If James is applying the concept of "the poor" in this sense, the word "faith" should be understood as a belief that makes someone trust in God. This kind of belief should involve the correct understanding of God's will, which should lead to wholehearted obedience.

Withal, why does the author of LOJ speak about this? The answer to this question can be seen in a constituent analysis of this unit.

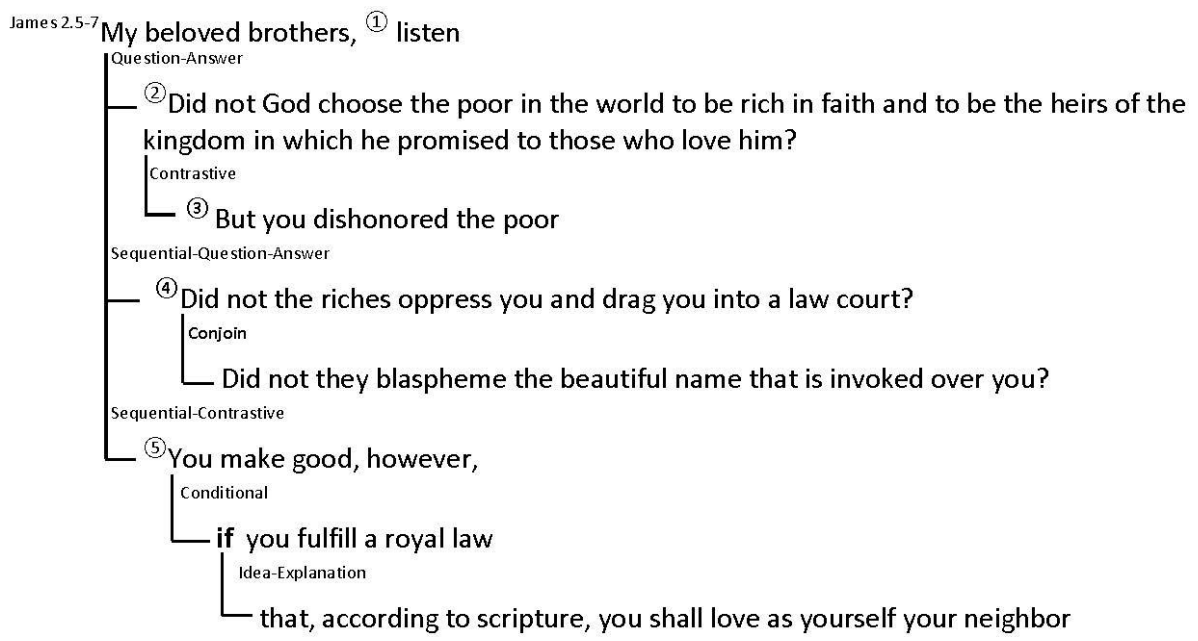

The analysis shows that the author of LOJ uses a strong word, "listen," and the literary style of question/answer to warn the hearers. The combination of both makes the sentence very strong. The word "listen" used by the author illustrates his authority. McKnight demonstrates that "listen" in biblical traditions is usually used by God and that it functions in LOJ

50 Cf. McKnight, The Letter of James, 194-195 
mainly to attract his readers' attention. ${ }^{51}$ Even so, the tone used by LOJ apparently suggests more than what McKnight thinks. The contrast statement (in colon (3)) used by the author to answer the question asked in colon (2) reveals that the author of LOJ was rebuking the hearers. The other sequential "interrogative questions" in colon (4) also emphasizes the similar correction that the hearers had an inconsistent faith; they already knew that God is the only judge and that he loves, protects, and cares for the poor, but they patronized the poor anyway. This would not have been the case if they had true faith because those who truly believe in God will integrate their belief with their actual life.

The issue of true faith dominates the conversation between the author of LOJ and his hearers until the end of James 2.52 Before the author of LOJ speaks about faith and works in James 2.14-26, in 2.5-11 he clarifies God's will for his people, particularly, his desire regarding how the poor should be attended to, and in James 2.12-13, the author of LOJ ends the exhortation by warning them of God's vengeance, especially if they fail to repent and stop practicing preferential treatment. ${ }^{53}$ And this leads to unit 6 (James 2.14-26), videlicet, the last unit in James 2.

51 McKnight, The Letter of James, 192.

52 The theme of true faith is still important in James 3, 4, and 5. The author of LOJ in James 3.112 reminds the audience that true faith leads to trusted and loving speech, which need not be censured. James 4.1-12 speaks about true faith that should make believers not live in accord with sinful desire but in accord with God's will; moreover, in James 4.13-16, the author speaks about true faith in making a plan. Interestingly, similar to James 1, the author of LOJ in James 5.1-17, returns to his discourse on the importance of true faith in believers' sufferings.

53 The author of LOJ apparently shares the Jesus tradition with Matthew (cf. 5.3) and Luke (cf. 6.20). The similarity between LOJ, Matthew, and Luke indicates that they probably share a tradition that proclaims the poor as those who are blessed and who will inherit the kingdom of God. The discussion about how and why the author of LOJ uses this tradition is beyond the scope of this essay. 


\section{The Concept of Faith in James 2.14-26}

The concept of faith in this section is complicated; different perspectives used by an interpreter lead to diverse conclusions when they expose this text. Analysis of unit boundaries can show that the subject of conversation is the shift between James 2.14-17, 2.18-23, 25, and 2.24,26. The conversation in 2.14-17 is between the author of LOJ and the hearers, but it changes in 2.18-23, 25 in which the object of conversation is with a hypothetical dialogue partner. After this, the author resumes his address to the hearers again at 2.24, 26.54 It seems as though the author intentionally creates this structure and inserts elements of a dialogue (with the hypothetical partner) to enhance the main thrust of his argument.

\footnotetext{
54 Many scholars suppose that the use of a hypothetical dialogue in making an argumentation is characteristic of a diatribe. Bauckham confirms Stowers' argument, who argues that diatribe is used to deal with the issues of moral inconsistency, and this tendency also could be seen in LOJ. He also argues that since the dialogue partner in the diatribe is hypothetical, it is unreasonable to relate the dialogue partner in James 2.14-16 to Paul or the followers of Paul. (Bauckham, James, 60) If diatribe is in fact being employed in LOJ, it confirms Stowers' theory; the author of LOJ in James 2.18-23, 25 probably is attempting to persuade his hearers to the necessity of living in consistency with their confession of faith. Despite this, there is also a possibility that the author of LOJ uses the literary form of "dialogue," one that is utilized in wisdom literature; the hypothetical dialogue used in conversations is also the character of this literary form; see James L. Crenshaw, Urgent Advice and Probing Questions: Collected Writings on Old Testament Wisdom (Macon: Mercer University Press, 1995), 68-70. On the other hand, Bauckham's conclusion about whether there are Pauline tracks in James 2.14-26 is convincing; there is no track of Paul in James 1-2; the analysis in this essay shows that the author of LOJ does not concern himself with erroneous doctrines, like works-righteousness based on the law; rather, his concern is centered upon the believers' faith bearing fruit through the consistency of good deeds.
} 
Faith Conversation with the Hearers (Jas 2.14-17)

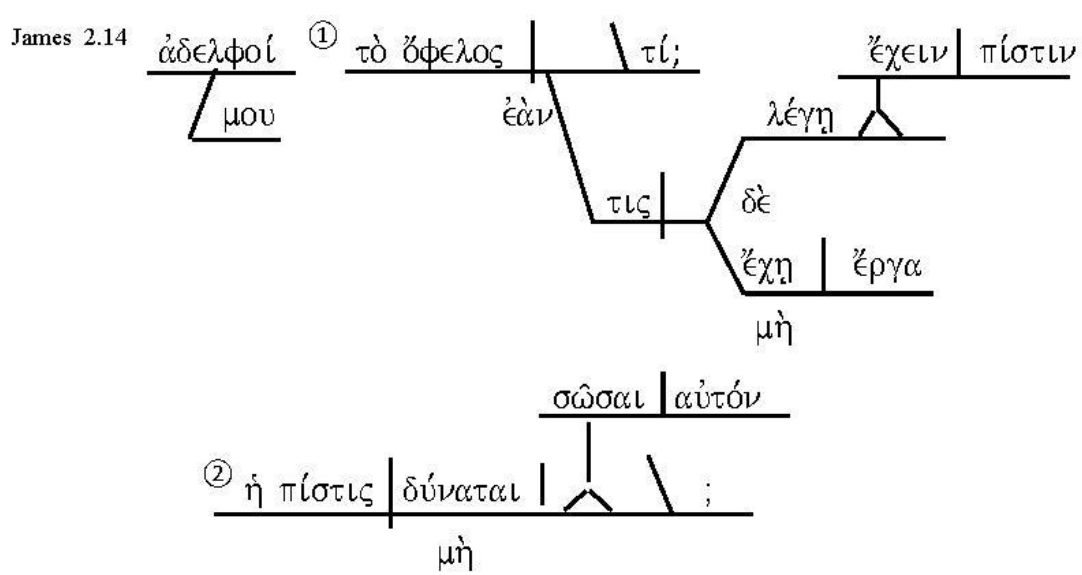

James 2.15-16

James $2.17 \quad \kappa \alpha i$

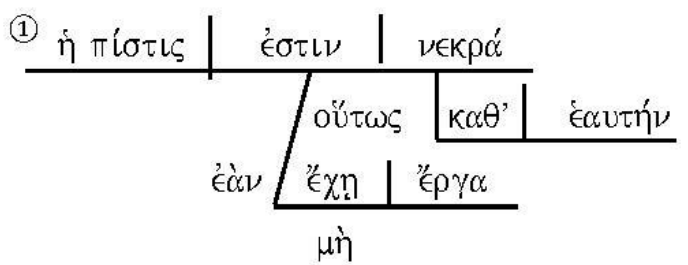

The word "faith" is used twice in James 2.14 andonce in 2.17. The word "faith" used in the phrase "one who say to have faith" could be understood as a professing of belief or a doctrinal belief. ${ }^{55}$ The author of LOJ does not oppose doctrinal or professing belief; instead, he maintains that professing belief and doctrinal confession should be practiced in actual life. This is the literary context connecting all units of James 1-2. This literary context should be used to understandthe worde;rgaemployed in James 2-1426 , which bears no connection to the Pauline expression " $€$ $\rho \omega v v o ́ \mu o v$. While Paul uses the phrase to speak about circumcision, the food law, and the law of Sabbath, the author of LOJ uses the word " $\rho \gamma \alpha$ to speak about "visiting

55 See Bauckham, James, 121; Davids, The Epistle of James, 119. 
orphans and widows" (Jas 1.27) and "honoring and loving the poor" (Jas $2.6,8) \cdot{ }^{56}$

Furthermore, James 2.15-16 contains a rhetorical question and an example used to support the author's main argument that faith is affirmed by the consistency of one's actions/deeds. ${ }^{57}$ With this in mind, the author of LOJ uses exemplification to show his hearers that "a saying" is useless

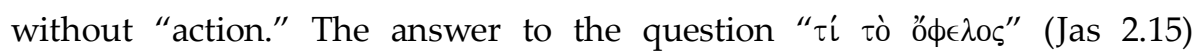
probably led the hearers to finally accept that "action-less faith" is not really

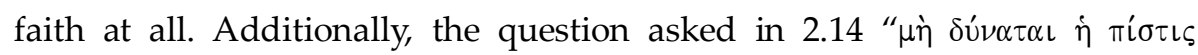

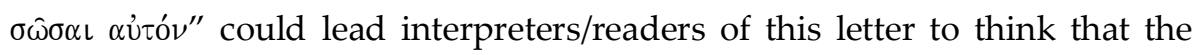
author is speaking about faith in the context of salvation. ${ }^{58}$ Even so, this question should be understood in its relation to the example given in James 2.15-16. The author uses this example to illustrate that it is not enough to speak kindly to the needy; a true believer must self-sacrificially extend assistance to others. In addition, the example also makes use of irony; some individuals in the believing community did nothing to help the needy,

\footnotetext{
56 Cf. Davids, The Epistle of James, 122-13. Louw and Nida (Greek-English Lexicon, 511-516) find that the word " $€$ pov is used in the semantic domain "Perform, Do." This word could also be identified as a member of the semantic fields "Do, Perform" and "Work, Toil." In the first

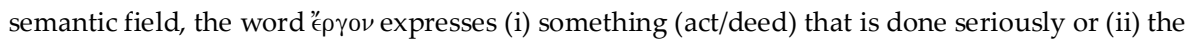
result of someone's activity or work. In the second semantic field, the word " "something (specifically, a task) that people normally do." Since the author of LOJ believes that faith and works are inseparable, the word " $€ \gamma \gamma \alpha$ in James 2.14-26 could be seen as the result of "the act of believing in God and Christ." While the author of LOJ believes that faith is "a belief that makes believers live in accord with God's will," then "€p $p \alpha$ is the concrete obedience performed by believers as the result of living in accord with God's will, and in James 1-2, this concrete obedience refers to loving and caring for the poor such as widows and the orphans.

57 Bauckham believes that the faith in this unit is "professing faith" done without practicing it. (James, 59) I agree with Bauckham that the issue of faith in this unit is related to a faith shown in speaking but not integrated with life. The example used in James 2.14-16 makes it clear that, without real charitable actions to follow, kindly speaking to the downcast is absolutely useless; in addition, the illustration made about demons' faith that is better than the faith of the hypothetical dialogue partner demonstrates that "wrong faith" is related to a saying used to make a statement of faith. Yet as it has emphasized that the author did not say that confession of faith is not important; his emphasis is that believers should live in accord with the true belief. 58 Cf. Davids, The Epistle of James, 120.
} 
although they called the needy a brother and a sister. These descriptions refer to those who refuse to live in accord with their belief; and in the literary context of James 1-2, these individuals are not different from those who are double-minded, who dishonor the poor. Since these individuals refer to those who distrust God, it could explain why LOJ underlines that this kind of faith will never be able to save anyone.

Based on its semantical function, James 2.17 is arranged as a sequential-reference. It means that this unit could function as a conclusion. Within it, the author of LOJ uses strong words in saying that faith is dead if it has no works. Bullinger $(1968,537)$ identifies that the author of LOJ uses "hypallage" in this colon as a figure of speech. 59 In the context of this figure of speech, the phrase "faith ... is dead" means "the man who says he has such faith is dead." The metaphor "dead" in this sentence refers to unbelievers or unfaithful individuals who do not live in accord with God's will. If Bullinger's interpretation is accurate, it confirms the previous conclusion that the literary context of James 2.14-26 is related to the faith of those who do not trust in God.

59 Bullinger (Figures of Speech, 535) defines "hypallage" as the literary style used to make an "interchange of construction in whereby an adjective or other word, which logically belong to one connection, is grammatically united with another, so that what is said of or attributed to one thing ought to be said of or attributed to the other." 
Faith Conversation with a Hypothetical Dialogue Partner

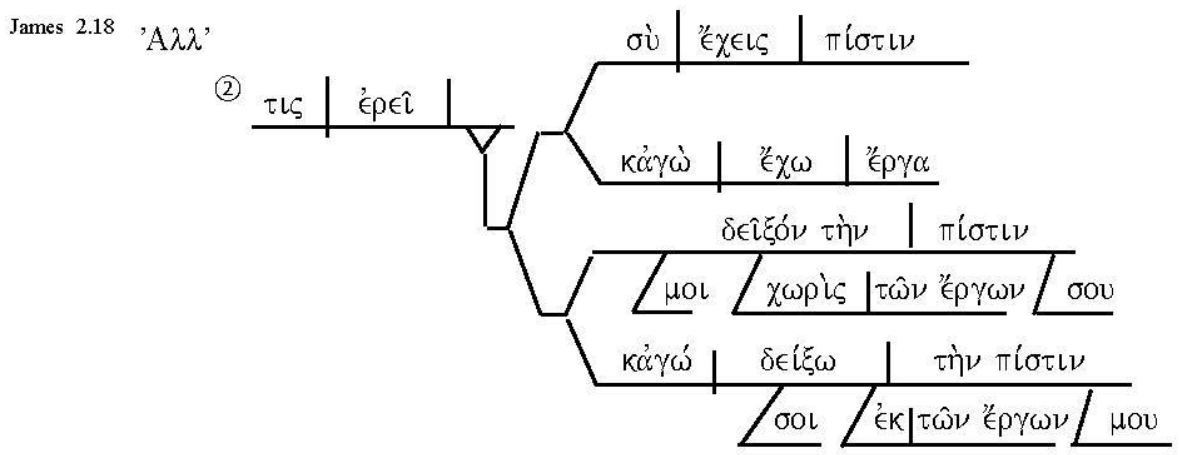

James $2.19-20$

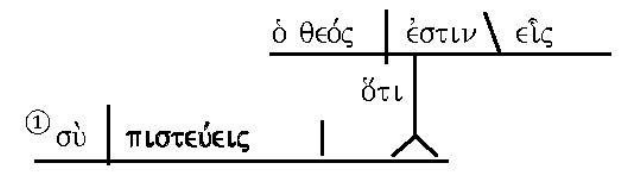

(2) $\frac{\mid \pi 0\llcorner\epsilon \hat{\iota} \zeta \mid}{\kappa \alpha \lambda \hat{\omega} \zeta}$

$\kappa \alpha i$

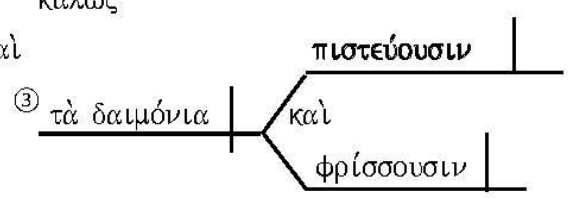

$\delta \dot{\epsilon}$

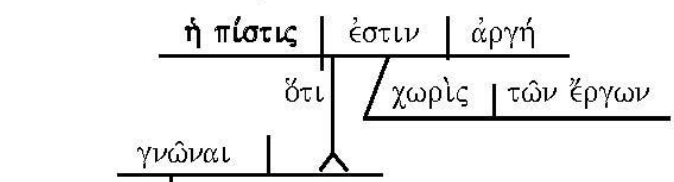

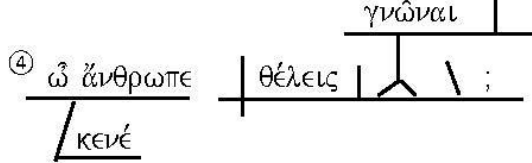

James 2.21 
James. 2.22-23

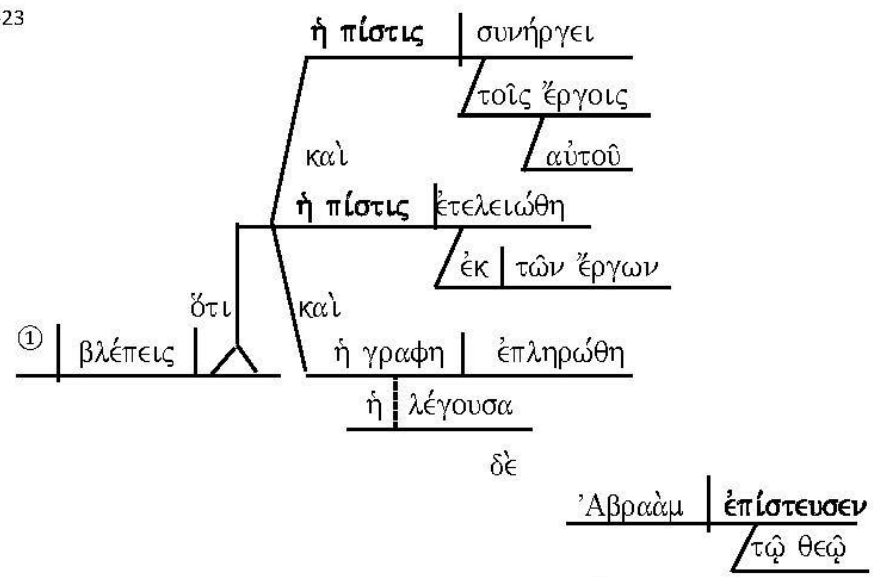

kà

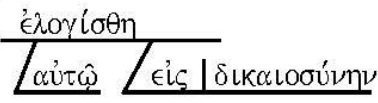

kà

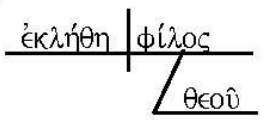

James 2.25

The author of LOJ discusses questions from a hypothetical dialogue

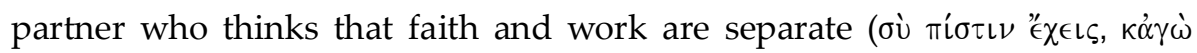
${ }^{\prime \prime} \rho \gamma \alpha$ " $\chi \chi \omega$; see colon (2). ${ }^{60}$ The author of LOJ refutes this hypothetical counterargument in two ways. First, he argues that the faith which is only "a saying" is the precise description of what demons possess (see James 2.19-20 colon (3). Second, he uses Scripture as the model to show that faith is not only "a saying," but it should also be integrated in one's daily lifestyle (see James 2.22, 23, 25). After posing these arguments, the author makes the implication by asking the hypothetical dialogue partner to repent from his misunderstanding (cf. James 2.24, 26). ${ }^{61}$

60 James 2.18 is still connected to 2.17 (colon (1)).

61 How the author of LOJ builds the structure of his dialogue reveals that this is taken probably from a sermon. As stated above, the "inclusio" used in the beginning and end of this unit and the examples taken from Scripture, is the character of ancient homily. Still and all, how could one reconcile the use of diatribe and homily in the same unit? There are two possible 
The conjuction $A \lambda \lambda$ 'in James 2.18 indicates that the cola in this unit are related to the previous one (James 2.17). In the previous unit, the author of LOJ says that those who say they have faith but do not live in accord with their belief are essentially dead (the state of unbelievers); in this unit the author of LOJ uses two cola to underline differences between those who believe in God and those who are not. In James 2.18 and 2.19-20, the author of LOJ uses positive and negative sentences to differentiate these two kinds of people. In cola 2.18, he shows that fake believers (those who are only able to confess their faith but do not live in accord with it) will not be able to show that they truly live in accord with their belief. Then, in cola 2.19-20, the author of LOJ also shows that their confession of faith could even be done even by demons. ${ }^{62}$

Besides the positive and negative sentences, the author of LOJ also uses OT traditions to support his exhortations, to wit, those who truly believe in God will obey God's will, love God, and love their neighbor. The first example is taken from the story of Abraham (Jas 2.21, 23), and the second is taken from the story of Rahab (Jas 2.25). Bauckham shows that the author applies the story of Abraham to the actual situation because Abraham's faithfulness to God and his love to God are exemplary; moreover, the testing faced by Abraham confirms his faithfulness and his love for God. ${ }^{63}$ In addition, according to Davids, the story of Abraham and Rahab in LOJ are deliberately arranged together; ${ }^{4}$ although both stories are probably

explanations. First, the author of LOJ combined two different sources into one unit. The influence of the wisdom tradition in LOJ make the letter could adapt different literary styles and used them freely in accord with author's purpose. Second, there is a possibility that the literary style used in James 2.14-26 is not "diatribe" but "dialogue" that was probably known well in Jewish community and was also used in the wisdom tradition, such as in Wisdom of Solomon 2.1-20 (for a detailed discussion on the literary form of "dialogue," see Crenshaw, Urgent Advice, 67-70).

62 Davids (The Epistle of James, 125-126) holds that the author of LOJ is using this metaphor to accentuate that knowing God is not enough.

63 Cf. Bauckham, James, 122-123.

64 Cf. Davids, The Epistle of James, 133. 
independent, but the two stories are placed together and being related and united. 65 While the story of Abraham emphasizes his commitment to obey God, the story of Rahab shows her hospitality. Interestingly, the author apparently is attempting to highlight the connection between true faith and hospitality; and at the same time he also shows that the true faith will make believers have hospitality. 66

Thus, in this section, the author of LOJ makes clear that true faith is never only a confession. Similarly, he also emphasizes that true faith is validated by the consistency of one's charitable deeds.

\section{Concluding Conversation about Faith with the Hearers}

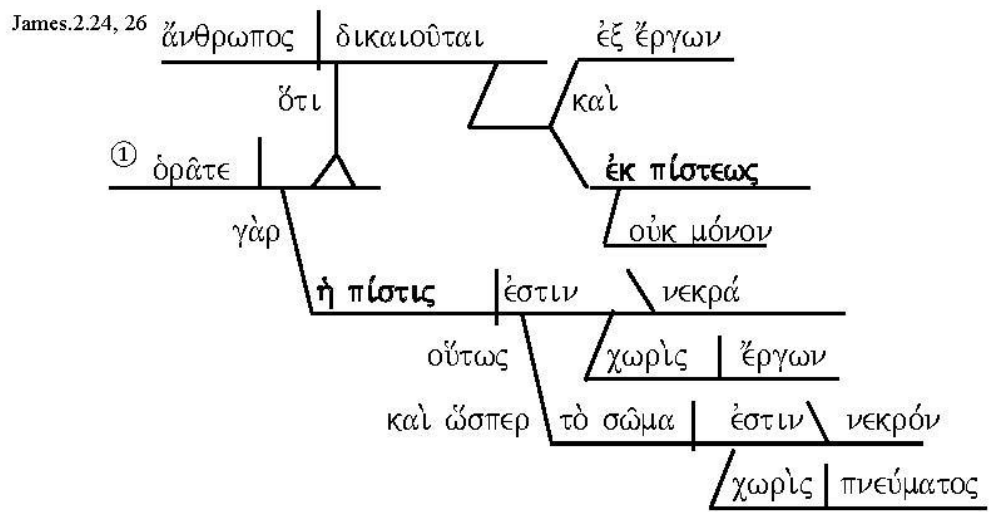

65 Many scholars (see, e.g., James D. G. Dunn, "Faith," in The New Interpreter's Dictionary of the Bible Vol. 2, edited by K. D. Sakenfield [Nashville: Abingdon, 2007], 421-422) hold that James used the tradition of Abraham to argue against Paul who also uses the same story in his teaching. However, the aim and the traditions used by James are different from Paul's. James's purpose in using the story of Abraham does not relate to the issue of circumcision; in contrast, he uses the Abraham story to show the importance of obeying God in the life of believers (cf. Bauckham, James, 122-123). The author of LOJ also uses the story of Rahab to emphasize the importance of hospitality in the life of believers. The use of OT teaching in LOJ is closely related to the function of LOJ as a pastoral letter.

66 The word бuvท́ $\rho \gamma \in \mathrm{L}$ used by the author in James 2.22-23 should be understood in its relation to the word " $\mathrm{p} p \mathrm{\gamma ov}$. Since the word " $\mathrm{k} p \mathrm{\gamma ov}$ is used in this unit to emphasize the result of an action

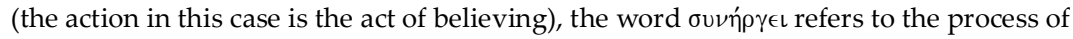
"resulting in something." In other words, the works (specifically, loving and caring for the poor) are seen as the consequence of true faith. 
The author of LOJ makes a conclusion in this section. Three ideas are used in his conclusion. The author uses a more persuasive word here; he says ópôt $\epsilon \epsilon$ "you see ...." This persuasive approach is probably influenced by the diatribe used in this section. Further, the author of LOJ provides a few closing remarks. Based on the tradition of Abraham and Rahab, he proves that those who believe in God and who live in accord with their belief will be justified by God. Likewise, in this colon, the author seems to employ the creation tradition to accentuate that true believers will live in accord with their belief. ${ }^{67}$ Just as it is impossible to separate the animate body from spirit/breath (cf. Gn 2.7), so also is it impossible to separate lively belief from its works, that is, wholehearted obedience to God; those who say that they believe in God should have a commitment to obey God's will in their life and to love their neighbor.

To conclude, the concept of faith plays a pivotal role in James 1 and 2, and could bind the unit coherence in the texts. The concept of faith discussed in each unit shows a pattern. Throughout the letter, the author reinforces the necessity of living out authentic faith. The true faith in LOJ is not only a matter of confession; in fact, it is dangerous when the faith becomes only a matter of confession. Some individuals in the believing community had a problem with this issue, and LOJ was sent to call them to repent and to return to God. Furthermore, in James 1.2-15, the author of LOJ speaks about how important it is for believers to face their suffering in accord with their true belief; similarly, in James 2.1-26, he speaks about how important it is for believers to live in accord with their true belief by loving and caring others who suffer especially the poor.

67 Hartin, James, 156. 


\section{Conclusion}

The study on James 1-2 in this work shows that LOJ is not mainly a moral discourse, as some have read it. Although the author of LOJ uses the imperative form within every main idea in the main unit of James 1-2, the content shows that it is a pastoral letter. The letter was not sent to teach about morality in general, but it was sent to help believers dealing with the issue of suffering in the believing community. It wants to help the hearers understanding their sufferings from the right perspective and responding to them with the right actions. In this case, faith plays an essential role because it is only true faith that compels believers to live in accord with their belief. The letter also encourages the hearers to respond to the sufferings of others with empathy and love.

The concept of faith in LOJ is rather complicated. The author concedes that believers' faith in Christ should take the form of a clear confession - as well as trust and obedience. Consequently, the author saw that, in the believing community, the faith of some individuals was only a matter of confession. This kind of faith cannot patiently endure persecution, nor can it produce genuine goodness. This is why hypocrisy, favoritism, evil speaking, and other sins exist in the believing community. For this reason, believers need to ask for God's wisdom so that they are empowered by him to integrate their belief with their actual lives. 